The decrease of $\mathrm{NH}_{2} \mathrm{OH}$ appears from the curves in Fig. 1. The catalytical effect of blood hemoglobin and leghemoglobin is thus practically the same.

Nodules whose red colour had changed into green (the porphin ring of leghemoglobin has opened 7 ) and which thus had lost their $\mathrm{N}_{2}$-fixing capacity ${ }^{6}$ reduced hydroxylamine very poorly, or hardly at all. The reduction of hydroxylamine in root nodules is thus chiefly caused by leg. hemoglobin. This is confirmed also by the results of the experiments in which we compared the breakdown of hydroxylamine by the extract of effective nodules formed by pea bacteria, strain $H 43$, and ineffective nodules formed by pea bacteria, strain $H$ VIII. In the latter nodules no leghemoglobin is to be found. Ascorbic acid was not added to the extracts. After a reaction time of $3 \mathrm{~h}$ the photometer readings were: in the experiment with effective nodules 83, in the experiment with ineffective nodules 152.

Formation of ammonia by breakdown of hydroxylamine was followed in some experiments. With an extract of the root nodules of soya, to which ascorbic acid had not been added, $0.28 \mu \mathrm{g}$ of $\mathrm{NH}_{2} \mathrm{OH}$ nitrogen disappeared during $3 \mathrm{~h}$, while $0.12 \mu \mathrm{g}$ of $\mathrm{NH}_{3}$ nitrogen was formed, which corresponds approximately to the equation: $3 \mathrm{NH}_{2} \mathrm{OH}=\mathrm{N}_{2}+\mathrm{NH}_{3}+3 \mathrm{H}_{2} \mathrm{O}$.

Experiments in which an eventual reduction of pyruvic acid oxime in root nodules was examined gave negative results. Increase of alanine as a reduction product of the oxime could not be observed in these experiments by using the paper chromatographic method. The method of determining the oxime is, however, uncertain as hydroxylamine to a great extent decomposes during hydrolysis when the solution contains organic substances like ascorbic acid.

Our findings show that an intensive breakdown of hydroxylamine takes place in $\mathbf{N}_{\mathbf{2}}$-fixing root nodules which contain leghemoglobin. As ascorbic acid is to be found in the nodules in relatively high concentration $(2-3$ times higher than in roots) $^{8}$ the reduction to ammonia is apparently practically complete in those hydroxylamine concentrations which may occur in the nodules if hydroxylamine is formed as an intermediate. In parallel experiments where the effect of red blood cells and red root nodules on the reduction of hydroxylamine in the presence of ascorbic acid was compared, the reaction velocity was found to be approximately the same. As the disappearance of hydroxy. lamine is very slight in ineffective and leghemoglobin-free root nodules, as well as in older ones where the leghemoglobin, because of the splitting of the porphin ring, has changed into green pigment, it is obvious that leghemoglobin is the main, or only, factor which causes the reduction of hydroxylamine in root nodules. In the case that hydroxylamine is formed as an intermediate in $\mathrm{N}_{\mathbf{2}}$-fixation in root nodules, leghemoglobin is thus indispensable in the reduction of hydroxylamine.

1. Taniguchi, S., Mitsui, H., Toyoda, J., Yamada, T. and Egami, F. J. Biochem. (Japan) 40 (1953) 175.

2. Zucker, M. and Nason, A. Federation Proc. 13 (1954) 328.

3. Colter, J. S. and Quastel, J. H. Arch. Biochem. 27 (1950) 368.

4. Schwyzer, R. Acta Chem. Scand. 5 (1951) 1398.

5. Virtanen, A. I. Nature 155 (1945) 747.

6. Csáky, T. Z. Acta Chem. Scand. 2 (1948) 450.

7. Virtanen, A. I. and Laine, T. Nature 157 (1946) 25; Virtanen, A. I. and Miettinen, J. K. Acta Chem. Scand. 3 (1949) 17.

8. Virtanen, A. I. and Jorma, J. Suomen Kemistilehti B, 18 (1945) 50.

Received October 3, 1954.

\section{Fixation of Molecular Nitrogen by Excised Nodules of the Alder}

ARTTURII. VIRTANEN, TAUNO MOISIO, RUSSELL M. ALLIS ON and R. H. BURRIS *

Laboratory of the Foundation for Chemical Research, Biochemical Institute, Helsinki, Finland, and Department of Biochemistry, University of Wisconsin, Madison, Wisconsin

$T_{\mathrm{s}}^{\mathrm{h}}$ he alder tree fixes molecular nitrogen at a rate sufficient to support vigorous growth on a nitrogen-poor soil. As it now is possible to demonstrate nitrogen fixation consistently with excised nodules from leguminous plants 1,2, it seemed advisable to test whether alder nodules also can fix nitrogen apart from the host plant.

* Fellow of the John Simon Guggenheim Memorial Foundation. 


\begin{tabular}{|c|c|c|}
\hline $\begin{array}{c}\text { Minutes } \\
\text { exposure } \\
\text { to }{ }^{15} \mathrm{~N}_{2}\end{array}$ & \multicolumn{2}{|c|}{ Atom per cent ${ }^{15} \mathrm{~N}$ excess } \\
\cline { 2 - 3 } 30 & Experiment 1 & Experiment 2 \\
\hline \multirow{2}{*}{60} & 0.014 & 0.105 \\
& & 0.142 \\
& 0.064 & 0.153 \\
120 & & 0.114 \\
& 0.069 & 0.376 \\
& & 0.278 \\
\hline
\end{tabular}

Table 1. Fixation of nitrogen by excised alder nodules exposed for various periods to an atmos. phere containing $\mathrm{N}_{2}$ enriched with 45 atom per cent ${ }^{15} \mathrm{~N}$ excess. Only the fraction of the nodules soluble in $3 \mathrm{~N} \mathrm{HCl}$ was analyzed.

Alnus glutinosa plants were grown for 4 years in a greenhouse on a quartz sand substrate supplied with a nitrogen-free nutrient mixture ${ }^{3} ; \mathrm{N}_{2}$-fixation was very strong and the trees attained a height of $3-4 \mathrm{~m}$. At harvest, branches of the root system were cut, sand was removed, and the root nodules were detached. The nodules immediately were placed in Warburg type respirometer vessels, and these were attached to manometers and evacuated ${ }^{4}$. To remove atmospheric nitrogen, the vessels were evacuated twice and filled with oxygen. After a third evacuation, 0.3 atmosphere of a mixture of 2 parts oxygen and one part ${ }^{15} \mathrm{~N}_{2}$ was added, and argon then was added to atmospheric pressure. The $\mathrm{N}_{2}$ was enriched with 45 atom per cent ${ }^{15} \mathrm{~N}$ excess, and the nodules were exposed to it for 0.5 to 2 hours in the vessels which were shaken in a water bath at $24^{\circ}$. The nodules then were remov. ed and ground with $3 \mathrm{~N} \mathrm{HCl}$ in a mortar. The ground material was centrifuged, and only the soluble supernatant solution was analyzed for ${ }^{15} \mathrm{~N}$ with a mass spectrometer.

Table 1 indicates the fixation of ${ }^{15} \mathrm{~N}_{2}$ by excised alder nodules in 2 experiments. It is evident that excised alder nodules fix a readily detectable quantity of molecular nitrogen in their acid soluble material. We generally consider that 0.015 atom per cent ${ }^{15} \mathrm{~N}$ excess indicates positive fixation, and in the most active alder nodules over 20 times this level was fixed in 2 hours.

Crushing or slicing the nodules decreased their fixation during a 2 hour exposure to ${ }^{15} \mathrm{~N}_{2}$ to between a fourth and a sixth that observed with intact nodules. Fixation was very limited in tests to determine the influence on fixation of exposure of the plants to light or dark - nodules from illuminated plants had 0.014 atom per cent ${ }^{15} \mathrm{~N}$ excess, whereas nodules from plants darkened for a day or for 3 days before removing their nodules for a 2 hour exposure under ${ }^{15} \mathrm{~N}_{2}$ had 0.006 and 0.005 atom per cent ${ }^{15} \mathrm{~N}$ excess, respectively. Addition of oxalacetate, alpha-ketoglutarate, malate or sucrose stimulated fixation of ${ }^{15} \mathrm{~N}_{2}$ by alder nodule slices only slightly. Experiments designed to establish the rate of fixation in whole nodules, rather than the soluble portion only, were unsuccessful, for the inert nitrogenous compounds diluted the ${ }^{15} \mathrm{~N}$ of the more active soluble fraction to a level too low for accurate estimation.

Fixation of nitrogen by excised alder nodules can be demonstrated readily with ${ }^{15} \mathrm{~N}$ as a tracer, but factors influencing the fixation are not yet sufficiently well under control to assure uniform results. With an improved understanding of these controlling factors, the use of excised nodules should stimulate studies of nitrogen fixation and the interesting nitrogen metabolism ${ }^{5}$ of the relatively neglected alder plant.

1. Aprison, M. H. and Burris, R. H. Science 115 (1952) 264.

2. Aprison, M. H., Magee, Wayne, E. and Burris, R. H. J. Biol. Chem. 208 (1954) 29.

3. Virtanen, A. I. and Saastamoinen, S. Biochem. Z. 284 (1936) 72.

4. Umbreit, W. W., Burris, R. H. and Stauffer, J. F. Manometric Techniques and Tissue Metabolism, Burgess Publishing Co., Minneapolis 1949 , p. 44.

5. Miettinen, J. K. and Virtanen, A. I. Acta Chem. Scand. 7 (1953) 289.

Received October 2, 1954. 